\title{
A 360-Day Administrative Year in Ancient Israel: Judahite Portable Calendars and the Flood Account
}

\author{
Jonathan Ben-Dov \\ Tel Aviv University; jonbendov@tauex.tau.ac.il
}

\begin{abstract}
Administrators in ancient Judah used schematic 30-day months and a 360-day year alongside other annual frameworks. This year was never practiced as a "calendar" for any cultic or administrative purpose, but rather served as a convenient framework for long-term planning, as well as for literary accounts that were not anchored to a concrete calendar year. Examples for such a usage are attested here from Mesopotamian texts. Material evidence for the 360-day year in Judah comes forth from a series of small perforated bone plaques from various sites in Iron Age Judah. One such item was recently unearthed in the city of David. These objects can reasonably be understood as reflecting a schematic 360-day year, serving as desk

* This paper was presented at the 2017 Mid-West meeting of ASOR and SBL. I am grateful to JoAnn Scurlock, Richard Beal and Eric Mason for the invitation and hospitality. Eshbal Ratzon offered valuable comments and so did the readership of HTR. Thanks are due to Ronny Reich for introducing me to the Judahite calendar plaques and especially to the unique item from the city of David. This study owes much to the views of Fred H. Cryer, "The Interrelationships of Gen 5,32; 11,10-11 and the Chronology of the Flood (Gen 6-9)," Biblica 66 (1985) 241-61; idem, "The 360-Day Calendar Year and Ancient Jewish Sectarianism," SJOT 1 (1987) 116-22. I share Cryer's insights and further buttress them by enriching the background for the Ancient Near Eastern use of schematic years, as well as by adding archeological evidence from Iron Age Judah. At the same time, I offer significant modifications to his claims.
\end{abstract}

\footnotetext{
(C) The Author(s), 2021. Published by Cambridge University Press on behalf of the President and Fellows of Harvard College. This is an Open Access article, distributed under the terms of the Creative Commons Attribution-NonCommercial-ShareAlike licence (https://creativecommons.org/licenses/by-nc-sa/4.0/), which permits non-commercial re-use, distribution, and reproduction in any medium, provided the same Creative Commons licence is included and the original work is properly cited. The written permission of Cambridge University Press must be obtained for commercial re-use.
} 
calendars for Judahite administrators. Several priestly pentateuchal texts are best understood against this background, such as the dating of some festivals and most notably the dates in the Flood narrative (Gen 7-8). The original dating system is best represented in LXX Gen 7:11, while the reading of MT is a late modification, inserted later, when calendar debates took a central place in the religious discourse. MT is thus a link in a chain of later reworking of this narrative in Second Temple literature. The 360-day year is thus a unique case where material culture dovetails with literary evidence, and may shed light on the material culture of priestly sources. This insight is significant for future studies of biblical time reckoning.

\section{Keywords}

calendars in the Hebrew Bible, Flood narrative, calendar plaques, schematic calendar, priestly source, City of David, Lachish, Aroer

\section{Introduction: The Schematic Year}

Ancient states and societies used different kinds of time reckoning for various purposes. For example, in classical Athens the archontic lunar calendar was practiced alongside the schematic prytanic calendar, as recorded in numerous double dated documents. ${ }^{1}$ Furthermore, documentation from Ancient Egypt attests to a dual calendrical system, whereby people paid their taxes according to the civil year of 360 days +5 additional days, but festivals were celebrated in the temples according to a lunar calendar. ${ }^{2}$ We should thus be open to various temporal systems functioning in each society.

Societies, ancient and modern alike, use schematic calendars, which find particular favor among clerks and administrators. Consider a case in which one needs to calculate the amount of grain required to feed a squad of one thousand slaves through a multi-year construction project, with a known quantity of grain per slave per day. This calculation would be rather difficult under a lunar calendar because one cannot tell in advance when an intercalation will take place, adding thirty days to one or more of the years. ${ }^{3}$ The clerk will need to wait until the very last day of the month in order to know whether it has twenty-nine or thirty days. In addition, it cannot be taken for granted that kings sought to maintain the calendar's correspondence to nature, because sometimes they would rather postpone the new moon by a day or so, thus postponing the payment of their debts. ${ }^{4}$ Long-term

\footnotetext{
${ }^{1}$ See the updated discussion of this phenomenon in Sacha Stern, Calendars in Antiquity: Empires, States, and Societies (New York: Oxford University Press, 2012) 26-49.

2 Anthony J. Spalinger, "Calendars," OEAE, 1:224-27, with further bibliography cited there. For a recent, more moderate assessment of the evidence on the Egyptian lunar calendar, see Stern, Calendars in Antiquity, 159-61.

${ }^{3}$ For the administrative difficulties caused by the lunar calendar, see Living the Lunar Calendar (ed. Jonathan Ben-Dov, Wayne Horowitz, and John Steele; Oxford: Oxbow: 2012).

${ }^{4}$ Francis M. Dunn, “Tampering with the Calendar," ZPE 123 (1998) 213-31; Stern, Calendars in Antiquity, 29-31.
} 
calculations are nearly impossible under such a calendar regime. A schematic calendar, in contrast, avoids these problems by employing a fixed number of days or other fixed calendrical structures. A schematic year is useful not only for long-term calculations, but also when the need arises in literature or in science to express a date formula which could work for any given year, without pinpointing a concrete date based on a concrete astronomical observation.

While a schematic year may function as a calendar in the real world, it may also exist solely as an administrative construct. The Julian or Gregorian year is an example of the first kind, being schematic yet enacted in practice, a combination which won it enormous success. In contrast, some periods in ancient Mesopotamian history attest to the use of a schematic year which was divorced from the civil and religious calendar, as discussed below.

In the present article I highlight the use of schematic months and of a schematic 360-day year in Ancient Israel. I cite different kinds of evidence, both material and literary, whose understanding could greatly benefit if interpreted as using a schematic time reckoning. While not every piece of evidence cited here is entirely conclusive, the accumulation of evidence from various branches of biblical studies render the presence of a schematic calendar in ancient Israel plausible. In turn, I hope to show how this kind of schematic year was treated in later Second Temple times, when debates about the calendar took a more central place in the religious discourse. My suggestion has the potential to elucidate some famous cruxes, mainly the debate about the dates in the flood account (Genesis 7-8), as represented in the biblical versions.

In ancient Mesopotamia until the Old Babylonian period, the most wide-spread system in administrative use was a schematic year of 360 days, existing alongside the lunar calendar. ${ }^{5}$ Many economic and calendrical documents from the third millennium BCE attest to the use of such a year, which functioned as the main framework for accounting: inventories, tax calculations, and long-term planning. The same number was used to express schematic time periods that did not involve long-term calculations, when no recourse to a concrete year was required. A few examples will help clarify the matter.

The tablet TCL 5, 5669 (AO 05669) is an administrative Ur III text from the reign of Shulgi (twenty-first century BCE) at the Sumerian city of Umma. ${ }^{6}$ The author assigns groups of female slaves to various work sites across the city and its environs, calculating the amount of work-days assigned to each site and the ensuing requirements of food for various periods of time. The first section (I 1-5), for example, reads:

\footnotetext{
${ }^{5}$ Robert Englund, "Administrative Time Keeping in Ancient Mesopotamia," JESHO 31 (1988) 121-85; Lis Brack-Bernsen, "The 360-Day Year in Mesopotamia," in Calendars and Years: Astronomy and Time in the Ancient Near East (ed. John Steele; Oxford: Oxbow, 2007) 83-100.

${ }^{6} \mathrm{~A}$ hand-copy, transliteration and translation of this text are conveniently found in the Cuneiform Digital Library Initiative (http://cdli.ucla.edu) under the CDLI number P131740. The text is mentioned in Englund, "Administrative Time Keeping," 126-27.
} 
Thirty-six female laborers

from month "Harvest"

to month "Dumuzi,"

their labor: 12,960 days

are the debit

In this site thirty-six slaves will work for exactly one year (i.e., from month 1 to month 12 in the Umma calendar). ${ }^{7}$ The scribe calculates the number of work days as $36 \mathrm{X}(12 \mathrm{X} 30)=12,960$. The number of 360 days is implied by the multiplication of twelve schematic months with thirty days each.

Early administrators were aware that 360 is not a valid number for any year in practice. They were also aware that intercalation may be required, and therefore created a schematic intercalation system, with an added, thirty-day long thirteenth month every third year. ${ }^{8}$ Neither number - 360 or 390 days — was applicable in reality to any civil-agricultural year. This kind of discrepancy between the schematic calendar and the year in practice is inevitable. Administrators expected the gap to occur and handled themselves with a margin of error accordingly.

A different usage of the schematic year can be seen in the document IM 80213, an ikribu prayer to the goddess Ninsianna by one Ur-Utu (lit. the dog [=servant] of Šamaš), a priest from Sippar-Amnānum (Der) of the Old Babylonian period. ${ }^{9}$ Ur-Utu seeks the favorable face of his goddess as he asks her advice in divination. The petitioner presents a sacrifice, in whose liver the divine answer is sought:

O God! My Divine mistress Ninsianna

Accept this offering

Stand by my offering

And an omen of welfare and life

Set to Ur-Utu, your servant.

Concerning Ur-Utu, your servant, maintain your presence,

For the sake of the prayer hereby offered

From the twentieth day of Nisan

Until the twentieth day of Nisan of the coming year,

6 X 60 days, 6 X 60 nights. . . .

Will Ur-Utu have or not have life and well-being?

Temporality played an important part in oracle queries. Each omen had a period of validity, adannu, which could not be exceeded..$^{10}$ This particular prayer, however,

${ }^{7}$ For the Umma calendar, see Mark E. Cohen, Festivals and Calendars of the Ancient Near East (2nd ed.; Bethesda, MD: CDL Press, 2015) 168-91; and in more detail, Richard Firth, "Synchronization of the Drehem, Nippur and Umma Calendars During the Latter Part of Ur III," CDLJ (2016) 1-12.

${ }^{8}$ See Englund, "Administrative Time Keeping," 143-44.

${ }^{9}$ Published by Léon de Meyer, "Deux prières ikribu du temps d'Ammi-ṣaduqa," in Zikir Šumim: Assyriological Studies Presented to F. R. Kraus on the Occasion of his Seventieth Birthday (ed. G. van Driel et al.; Studia Francisci Scholten memoriae dicata 5; Leiden: Brill, 1982) 271-78; see Takayoshi Oshima, Babylonian Prayers to Marduk (Orientalische Religionen in der Antike 7; Tübingen: Mohr Siebeck, 2011) 29.

${ }^{10}$ Niels Heeßel, "The Calculation of the Stipulated Term in Extispicy," in Divination and 
does not indicate the time of validity announced with the oracle, but rather the time frame requested by Ur-Utu before the sacrifice. The prayer and sacrifice were offered on the twentieth of the month, known as a sacred day for the cult of the sun god Šamaš. ${ }^{11}$ Ur-Utu asks for wellness through the coming year, from the twentieth of this month to the same date next year, 360 days altogether. This number is expressed quite elegantly in the cuneiform script as 6 X 60 days.

Ur-Utu was not obliged to mention the number of days, and could have only indicated the same calendar date next year, whatever number of days would pass in reality until then. But the efficacy of the ritual required a round number of days. While the modern punctilious reader may ask what happened in reality, when the actual year in Sippar lasted 354 days, or maybe 384 days, this question is in effect futile. The round number 360 is good for the efficacy of the oracle query, but it would be qualified by concrete numbers as the year advances and calendar decisions are made known.

The use of the 360-day year for accounting and administration lasted until the Old Babylonian period. The same number was used in cuneiform literature for astronomical calculations even later, throughout the first millennium BCE. The 360-day year was the standard for traditional Babylonian astronomy, and did not disappear until much later, in Greek astrology. ${ }^{12}$ Its use is expressed, for example, in a passage from the Babylonian "Diviner's Manual," known from copies in the library of Assurbanipal and elsewhere: "Twelve months per year; 360 its days. Hold in your hand the time of the start of the year. The disappearance of the moon, the 'corrections' of the dates of the (first) visibilities of the stars, the convergence of the beginning of the year with the Field. . . " 13

Interpretation of Signs in the Ancient World (ed. Amar Annus; OIS 6; Chicago: Oriental Institute of the University of Chicago, 2010) 163-76 (with earlier bibliography cited there). The term adannu is probably cognate to the Hebrew/Aramaic עידן; see Abraham Winitzer, "The Reversal of Fortune Theme in Esther: Israelite Historiography in Its Ancient Near Eastern Context," JANER 11 (2011) $170-218$, at 201-2 n. 118.

${ }^{11}$ Wayne Horowitz, "Sunday in Mesopotamia," in Living the Lunar Calendar, 9-18; Stefan Maul, "Gottesdienst im Sonnenheiligtum zu Sippar," in Minuscula Mesopotamica: Festschrift für Johannes Renger (ed. Barbara Böck, Eva Cancik-Kirschbaum, and Tonio Richter; AOAT 267; Münster: Ugarit-Verlag, 1999) 285-316, at 290.

${ }^{12}$ For Greek astrology, see, e.g., Vettius Valens, Anthologiae (ed. David Pingree; Bibliotheca scriptorum Graecorum et Romanorum Teubneriana; Leipzig: Teubner, 1986) 4.9 (160). For Babylonian astronomy, see Brack-Bernsen, "The 360-Day Year." David Brown, Mesopotamian Planetary Astronomy-Astrology (Groningen: Styx, 2000) 113-22, demonstrates in detail how the 360-day scheme functioned as a useful framework for generating many subsequent calculations in traditional Mesopotamian astronomy and mathematics. For the use of the 360-day year in astrology, see Matthias Albani, "Horoscopes in the Qumran Scrolls," in The Dead Sea Scrolls After Fifty Years: A Comprehensive Assessment (ed. Peter W. Flint and James C. VanderKam; 2 vols.; Leiden: Brill, 1999) 2:279-330, at 300 .

${ }^{13}$ See A. Leo Oppenheim, “A Babylonian Diviner's Manual,” JNES 33 (1974) 197-220; Clemency Williams, "Signs from the Sky, Signs from the Earth: The Diviner's Manual Revisited," in Under One Sky: Astronomy and Mathematics in the Ancient Near East (ed. John Steele and Annette Imhausen; AOAT 297; Münster: Ugarit-Verlag, 2002) 473-85; Brown, Mesopotamian Planetary 
The scholars of Babylonian astronomy were of course aware that no year will last exactly 360 days in practice, but they still used the 360-day year due to its benefit as a convenient base for further calculations, like those of the shadow length, the visibility of the moon, the length of daylight, etc. Rules were set to address the discrepancy between the schematic year and the concrete manifestation of the lunisolar calendar, for example the so-called "intercalation schemes" in the astronomical compendium Mul.Apin. ${ }^{14}$

The administrative use of the 360-day year in Mesopotamia ceased after the Old Babylonian period. The reason for this break is unknown and may be due to the development of accounting models that allowed for long-term calculations in the regular lunar calendar. In the following I do not claim that Judahite administrators continued the Babylonian tradition, which by then would have been obsolete. The Mesopotamian schematic year serves as an analogy to a similar-yet not identical - tradition, which arose in the early first millennium BCE among Judahite administrators.

\section{Archeological Evidence for the 360-Day Year in Iron-Age Judah}

I shall now examine in this light a series of material objects from Iron Age Judah, which give a good example for the everyday use of thirty-day months and of the schematic year by clerks and administrators. Admittedly, these items can be and have been explained as useful with other calendrical systems, but I believe that the schematic 360-day year better accounts for their material details.

In major sites from the period at the height of the monarchy, excavations yielded several portable calendars in the form of small, perforated bone plaques, with the holes arranged in numerical patterns. The find was surveyed and discussed by Nili Fox as part of her official publication of one such plaque found at 'Aro 'er. ${ }^{15}$ The following discussion builds on Fox's survey but suggests another possibility, unrecognized by her, for the kind of year reflected in the calendar plaques. Fox was not aware of the existence of a 360-day schematic year and hence did not consider it with regard to the calendar plaques.

The find includes nine plaques, found in major sites of Iron Age II Judah alongside other less prominent places: Lachish, Gezer, Tel el-Far'ah (south),

\footnotetext{
Astronomy-Astrology, 120-22.

${ }^{14}$ Hermann Hunger and John M. Steele, The Babylonian Astronomical Compendium Mul.Apin (New York: Routledge, 2019) 198-202, 209-13.

${ }^{15}$ Nili Fox, "A Bone-Carved Calendar," in Tel 'Aroer: An Iron Age II Caravan Town and the Hellenistic-Early Roman Settlement; Avraham Biran (1975-1982) and Rudolph Cohen (1975-1976) Excavations (ed. Yifat Thareani; Jerusalem: Annual of the Nelson Glueck School of Biblical Archaeology, 2011) 255-58, 468. Earlier bibliography is mentioned in Fox's article. Her discussion does not include the most recently found item from the city of David in Jerusalem, which also takes a different shape than the other items. That item was published by Ronny Reich, Eli Shukron, and Omri Lernau, "Recent Discoveries in the City of David, Jerusalem," IEJ 57 (2007) 153-69, at 162, and is discussed further below.
} 
Jerusalem, and 'Aro'er in the Negev. These are central sites concentrated in the south of Judah, Jerusalem being the most northern site and Tel el-Far'ah (south) the most southern one, standing very close to areas of Egyptian rule. This Judean phenomenon is not attested, to the best of my knowledge, in other regions. ${ }^{16}$

The holes drilled in these rectangular plaques are arranged in three lines of ten holes each, altogether thirty holes, with additional decorations separating the lines and adorning the edges of the plaque. The plaque was used by means of inserting pegs into the holes and advancing them along the days of the month and of the year, anticipating the later Greek habit of parapegmata. The Jerusalem plaque stands out as it contains three lines of only five holes each, altogether fifteen rather than thirty. The 'Aro 'er and Tel el-Far'ah (south) exemplars are adorned with a pronounced proto-Aeolic capital, the whole artefact resembling the shape of a column.
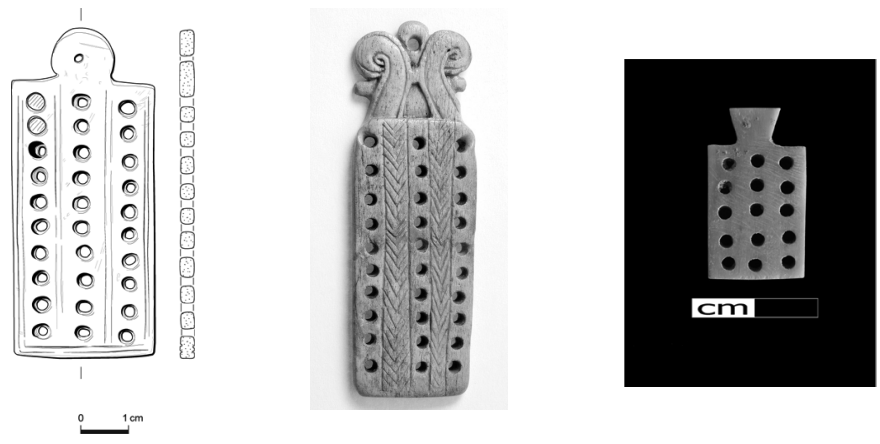

Fig. 1 (left): Plaque from Lachish. Drawing by Naama Earon, following Olga Tufnell, Lachish III: The Iron Age (2 vols.; Oxford: Oxford University Press, 1953) 2:23 (plate 56).

Fig. 2 (middle): Plaque from Tel el-Far'ah (south). (C) UCL Institute of Archeology. Fig. 3 (right): Plaque from the City of David. R. Reich and E. Shukron's Excavations in the City of David; Photographer: Vladimir Naikhin.

In addition to the peg holes, most plaques have one hole at the top, probably used for suspension. In contrast, the plaque from 'Aro 'er shows three holes rather than one at its top. The latter plaque is additionally unique in that it contains an additional vertical line of holes, this one numbering twelve holes. Altogether then, the 'Aro 'er plaque contains one line of twelve holes plus three lines of ten holes each, and in addition three holes at the top.

Already the first excavators, notably Flinders Petrie who exposed the item in Tel el-Far' ah, have suggested that these items served as small calendars with pegs inserted in the holes to mark the passage of every day. The item from 'Aro'er seems to verify this insight, since it is in effect a representation of the entire year

${ }^{16}$ See also a private correspondence by James Allen, as reported by Fox, "Bone-Carved Calendar," 258 n. 33. For a short discussion of the item from Tel el-Far'ah (south), see Sacha Stern, "Counting Time with Peg Holes," in Conversation Pieces: Inspirational Objects in UCL's Historic Collections (ed. M. Carnall; Oxford: Shire Publications, 2013) 68-69. 
with twelve months of thirty days each. ${ }^{17}$ The small size of these artefacts made them especially suitable for the private use of an administrator or clerk. Since the Jerusalem item was found in a pile of debris next to a large number of seals and bullae, an office environment seems reasonable. ${ }^{18}$ The 'Aro 'er item, in contrast, was found in a tomb. It might be that the scribe's personal items have been buried with him.

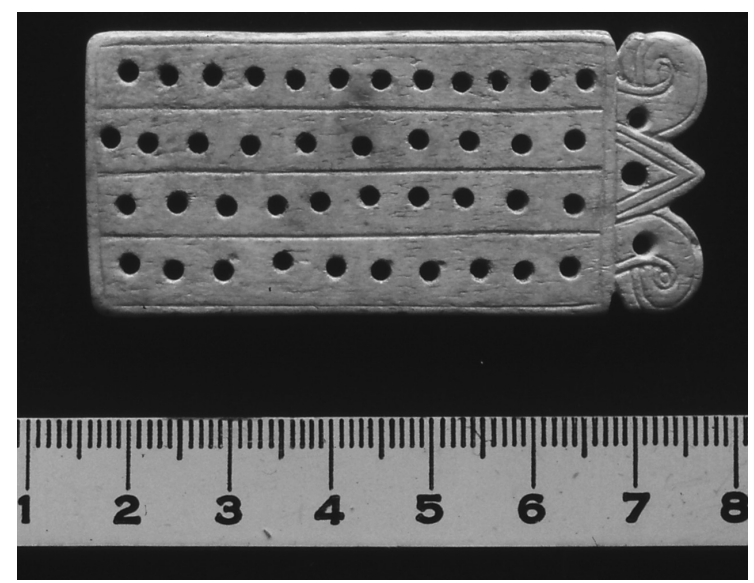

Fig. 4: Plaque from 'Aro'er. Courtesy the Hebrew Union College.

Being a trained expert in Egyptian archeology, Petrie suggested that the Far' ah item reflects the use of the Egyptian calendar of 12 X 30 days plus five additional days at the end of the year. ${ }^{19}$ The months in the Egyptian calendar are indeed schematic, a fact which gave credence to his assumption. The discovery of the 'Aro' er item lent further support to this hypothesis, since, as Fox has discerned, the three horizontal holes at the top of that plaque may represent the division of the Egyptian year into three seasons, with four months in each. The proximity of the find to the Egyptian region and the strong Egyptian cultural presence in Judean administration before the Assyrian conquest make this idea reasonable. ${ }^{20}$

Fox ultimately remains unsure that the plaques reflect the Egyptian calendar because it is unclear to her how the tripartite seasonal division of the Egyptian year

${ }^{17}$ This conclusion was announced by Avraham Biran, “And David Sent Spoils to the Elders in 'Aroer: Excavators Bring to Life Ancient Negev Fortress but Find No Remains from David's Time," BAR 9.2 (1983) 28-37.

${ }^{18}$ Reich, Shukron, and Lernau, "Recent Discoveries," 162.

${ }^{19}$ Flinders Petrie, Beth Pelet I (Tel Farah) (London: British School of Archeology in Egypt, 1930) 481.

${ }^{20}$ For the Egyptian cultural presence, see, for example, Pirhiya Beck, "The Art of Palestine During the Iron Age II: Local Traditions and External Influences (Tenth-Eighth Centuries BCE)," in Images as Media: Sources for the Cultural History of the Near East and the Eastern Mediterranean (1st Millennium BCE) (ed. Christoph Uehlinger; OBO 175; Göttingen: Vandenhoeck \& Ruprecht, 2000) 165-83. 
could be maintained in the Negev, far away from the inundation of the Nile. ${ }^{21}$ This difficulty leads her to offer a different, even less compelling, Phoenician connection. The above-cited objection should not harm Fox's case, however, because the Egyptian year was a wandering year, which had lost connection with the seasons. Since no intercalary days were added to the year, the gap of ca. 1/4 day between the length of the year and the true solar year accumulated to a serious degree of deviation. ${ }^{22}$ It could have thus been maintained as an efficient administrative framework also outside the Egyptian environment.

Other objections, however, speak against the connection of the Judahite plaques with the Egyptian calendar. The 'Aro'er item, with three holes at its top, is the only one of the nine plaques that shows the unit of three and the series of twelve monthly holes, while others really focus only on the thirty-day schematic month. Further, if the 'Aro'er item constitutes such a close reproduction of the year as Fox assumes, the problem remains that the internal order of the four months in each season is not represented in it, and could not be counted accordingly. Finally, none of the plaques allows for marking the five additional days at the end of the year, a crucial component of the Egyptian year. The Egyptian calendar option can thus be dismissed, especially because, in view of the preceding discussion, we now have a rather reasonable candidate for representation in the plaques: an administrative schematic year of 12 X 30 days.

Admittedly, the schematic use of the plates cannot be conclusively proven, because they may have been used also in the framework of the lunar calendar. In the case of a twenty-nine day month, the clerk would leave the last hole of the month unused (or skip the twenty-ninth hole) and begin the next month. ${ }^{23}$ Moreover, even if the plaques had been designed for use with the schematic calendar, they could be easily shifted for use under the lunar calendar. I see the plaque from 'Aro' er (Fig. 4) as an attractive visual representation of the schematic year, with a column of twelve months and three columns of ten days each. This schematic interpretation will be buttressed with textual evidence below.

The Jerusalem plaque (Fig. 3) attests to the same conclusion in its own unique way: instead of thirty holes it features fifteen holes, and was thus used twice in the course of a schematic month. ${ }^{24}$ This twofold division of the schematic month brings to mind the placement of various festivals in the middle of the schematic month by priestly writers, as discussed in detail below.

${ }^{21}$ Fox, "Bone-Carved Calendar," 256-57.

${ }^{22}$ Spalinger, "Calendars," 224-25; Stern, Calendars in Antiquity, 133-37.

${ }^{23}$ Note for example that in the Athenian calendar, the last day of the month would always be called "the thirtieth" regardless of its true length. See Stern, Calendars in Antiquity, 44-47.

${ }^{24}$ The bipartite division of the month, if indeed it existed beyond the practicalities of this single object, may correspond to the alleged early meaning of שבת as the day marking the middle of the month; see Alexandra Grund, Die Entstehung des Sabbats. Seine Bedeutung für Israels Zeitkonzept und Erinnerungskultur (FAT 75; Tübingen: Mohr Siebeck, 2011). 
How was the schematic administrative month divided? If we take the evidence of the calendar plaques seriously, it seems that the month was divided into three "decads," i.e., units of ten days each. ${ }^{25}$ The Jerusalem plaque may suggest a division into five-day "weeks." Interestingly, a division of the month into three decads was the norm in Egyptian time reckoning and bookkeeping. ${ }^{26}$ Given the considerable involvement of Egyptian methods in Judean administration, could it be that Judean scribes have also used decads as their basic division of the month?27

Yet another surprising insight arises from the Judahite calendar plaques: these devices did not seem to have used the seven-day week as an administrative unit of time. The week and the Sabbath may have been significant for the sacred division of time, but they were surely not used for mundane time reckoning until a much later period in time..$^{28}$ In fact, the earliest attestation for the use of the week in administration and commerce comes from Aramaic ostraca from the early(?) first century BCE..$^{29}$

To conclude this section, there are good grounds for claiming that the plaques attest to a bureaucratic use of schematic months and years in Iron Age Judah. This is not to say that schematic years were practiced in religious or civic use. Rather, it means that clerks and administrators used them when carrying out long-term

${ }^{25}$ This possibility is briefly supported also by Stern, "Counting Time with Peg Holes."

${ }^{26}$ Spalinger, "Calendars," 226. It was formerly suggested that the Nimrud wine lists from 8th cent. Assyria adhere to a cycle of ten days, but this view was refuted by F. Mario Fales, "A Fresh Look at the Nimrud Wine Lists," in Drinking in Ancient Societies: History and Culture of Drinks in the Ancient Near East (ed. Lucio Milano; Padova: Sargon, 1994) 361-80, at 367-69.

${ }^{27}$ For the Egyptian administrative environment in Judah, see Fox, "Bone-Carved Calendar," 258; eadem, In the Service of the King: Officialdom in Ancient Israel and Judah (Cincinnati: Hebrew Union College Press, 2000) 250-68; Bernd U. Schipper, Israel und Ägypten in der Königszeit: Die kulturellen Kontakte von Salomo bis zum Fall Jerusalems (Göttingen: Universitätsverlag; Vandenhoeck \& Ruprecht, 1999) 162-72.

${ }^{28}$ See Jonathan Ben-Dov, Head of All Years: Astronomy and Calendars at Qumran in their Ancient Setting (STDJ 78; Leiden: Brill, 2008) 59-66. I should emphasize that this debate is different from the question of whether Sabbath was observed as a day of rest in biblical times. While there may be evidence for this function of the Sabbath in Amos 8:5 and in the Yavneh-Yam inscription, these two sources do not employ the week, specifically not the days of the week, as an administrative time unit in everyday time reckoning. For the early history of the Sabbath, see Grund, Die Entstehung des Sabbats. Recently, Oded Tammuz, "The Sabbath as the Seventh day of the Week and a Day of Rest: Since When?" ZAW 131 (2019) 287-94, has claimed that Jews in Elephantine and Al-Yahudu abstained from signing contracts on the Sabbath, while Yigal Bloch has reached the exact opposite conclusion based on the same data: Bloch, "Judean Identity During the Exile: Concluding Deals on a Sabbath in Babylonia and Egypt under the Neo-Babylonian and the Achaemenid Empires," in A Question of Identity: Social, Political and Historical Aspects of Identity Dynamics in Jewish and Other Contexts (ed. D. Rivlin Katz et al.; Berlin: de Gruyter, 2019) 43-69. The matter must be investigated further.

${ }^{29}$ Ada Yardeni, "New Jewish Aramaic Ostraca," IEJ 40 (1990) 130-52; eadem, "Twelve Published and Unpublished Jewish Aramaic Ostraca written in the 'Jewish' Cursive Script," in In the Shadow of Bezalel: Aramaic, Biblical, and Ancient Near Eastern Studies in Honor of Bezalel Porten (ed. Alejandro F. Botta; Leiden: Brill, 2013) 209-43, at 210-18. 
calculations or referring to generic dates. This possibility is buttressed below with literary evidence from the Hebrew Bible.

\section{The 360-Day Year in the Hebrew Bible}

Some indications of time in the Hebrew Bible were not oriented towards a practical calendar, be it lunar, lunisolar, or any other system, but rather indicated schematic time. Date formulas appear quite often in the Hebrew Bible, but their astronomical regulation is never specified, leaving modern scholars with the need to hunt for clues, sometimes even to speculate. ${ }^{30}$ Given that many of the formulas do not relate to a concrete historical date but rather to general literary pronouncements, a schematic system would be rather useful. For example, the dates of the Israelite travel in the desert as given in the Priestly source obviously do not rely on a chronographic report from the time of Israel's wanderings but were rather generated by later authors using these authors' calendrical system. If this is so, some sort of schematic reckoning may be reasonably expected.

I suggest that many of the time indications in the Hebrew Bible functioned according to a schematic year, or more specifically, a year of 360 days constructed of schematic months of thirty days. This is not to say that civil or cultic calendars in ancient Israel functioned with this kind of month, but only that generic time formulas used them as a literary device. A short example from the Book of Esther will make the initial case:

The turn came for each girl to go in to King Ahasuerus, after being twelve months under the regulations for the women, since this was the regular period of their cosmetic treatment, six months with oil of myrrh and six months with perfumes and cosmetics for women. (Esth 2:12 [NRSV; italics mine])

The Book of Esther in general, and the details narrated in it in particular, show a strong hyperbolic nature, with a sense of exaggeration and a conspicuous note of parody. They cannot thus be considered historical in any concrete sense. ${ }^{31}$ My claim here is certainly not historical, but rather the opposite: I suggest that the author of Esther used schematic time periods as part of the hyperbole. This is also the case in the period of 180 days in Esth 1:3, a period that amounts to six schematic months of thirty days each, or half of a year. Similar logic pertains also to the cosmetic narrative encountered in $2: 12$.

\footnotetext{
${ }^{30}$ For a survey of calendars in the Hebrew Bible, see James C. VanderKam, "Calendars, Ancient Israelite and Early Jewish," ABD 1:814-20; Jonathan Ben-Dov, "Calendar and Festivals," The Oxford Encyclopedia of Bible and Law (ed. Brent A. Strawn; New York: Oxford University Press, 2015) 87-93; Philip Guillaume, Land and Calendar: The Priestly Document from Genesis 1 to Joshua 18 (LHBOTS 391; New York: T\&T Clark, 2009). Much of Guillaume's reasoning is debated below.

${ }^{31}$ Edward L. Greenstein, "A Jewish Reading of Esther," in Judaic Perspectives on Ancient Israel (ed. Jacob Neusner, Baruch A. Levine, and Ernst S. Frerichs; Philadelphia: Fortress, 1987) 225-43; Jon D. Levenson, Esther: A Commentary (OTL; Louisville: Westminster John Knox, 1997) 23-27.
} 
Why would each new wife be required to spend exactly twelve months in cosmetic treatment? While a variety of reasons may be suggested, I think that a calendrical interpretation will not be far-fetched, especially if it fits the general atmosphere of the accounts of the Achaemenid court. By calendrical interpretation, I do not mean to claim that the author provided concrete timing for the royal cosmetic office, but rather that a schematic image was conveyed, using schematic time periods. As part of the pompous (fictive) depiction of the Persian court, the author conceived that the king had 360 wives, one for every day of the schematic year; each new wife would be placed at the end of the queue, spending her first year at the harem in preparation for her royal rendezvous. Exactly the same image of a Persian harem is attested in Plutarch's biography of King Artaxerxes: ${ }^{32}$

This was the woman for whom Dareius asked, and he gave offence thereby to his father; for the Barbarian folk are terribly jealous in all that pertains to the pleasures of love, so that it is death for a man, not only to come up and touch one of the royal concubines, but even in journeying to go along past the wagons on which they are conveyed. And yet there was Atossa, whom the king passionately loved and had made his wife contrary to the law, and he kept three hundred and sixty concubines also, who were of surpassing beauty.

Although the number of wives is not attested in the Book of Esther as it is in Plutarch, I suggest connecting the two pieces of data, since both the Greek and the Hebrew authors employed the same kind of hyperbolic-fantastic or even parodic sense of the Persian kings and their pompous manners. ${ }^{33}$ In reality, Achaemenid kings followed either the Old Persian lunar calendar or the Zoroastrian calendar of 365 days, with neither of them amounting to 360 days. ${ }^{34}$ Nor did Plutarch intend to say that the king owned precisely one wife for each day of the Achaemenid year; it would therefore be irrelevant to ask how the harem handled the days in excess or in deficit of the number of 360 . This exactly is the force of the schematic year, an ideal figure for hyperbolic literary accounts, which are not necessarily tied to any calendar year in practice. ${ }^{35}$

${ }^{32}$ Plutarch, Art., 27.1-2 (Bernadotte Perrin, Plutarch: Lives [vol. 11; LCL; Cambridge: Harvard University Press, 1962]). I thank Dr. Eran Almagor for pointing out this source to me in a conversation many years ago. The motif of one concubine per day is attested elsewhere in Greek literature, as discussed by Carsten Binder, Plutarchs Vita des Artaxerxes: Ein historischer Kommentar (Göttinger Forum für Altertumswissenschaft. Beihefte 2.1; Berlin: de Gruyter, 2008) 343; Pierre Briant, From Cyrus to Alexander: A History of the Persian Empire (trans. P. T. Daniels; Winona Lake, IN: Eisenbrauns, 2002) 280-81.

${ }^{33}$ For other similarities between the Book of Esther and Greco-Roman traditions on the Persian court, see Adele Berlin, "The Book of Esther and Ancient Storytelling," JBL 120 (2001) 3-14, at 9 n. 18.

${ }^{34}$ Stern, Calendars in Antiquity, 170-78.

${ }^{35}$ Another trace for the schematic year used in the realm of divination may appear in the account of Haman's פור (lot) of chapter 3, a divinatory procedure with explicit calendrical ramifications. Winitzer, "The Reversal of Fortune," called attention to Haman's procedure with relation to the patterns of Babylonian divination, placing emphasis on the dates employed in the procedure. 
Schematic years and months are also attested in earlier biblical texts. They should be sought in Pentateuchal festival calendars, i.e., lists of festivals prescribing dates for annual festivals. ${ }^{36}$ Some festival lists do not mention dates at all (e.g., Exod 23:14-19), while others show so little concern with the calendrical apparatus that it remains impossible for modern scholars to know its characteristics. In the following I make use of the reasoning in an old article by John McKay which has not won much attention since its publication. ${ }^{37}$

Consider the dates assigned for the festivals of Sukkot and Matzot in the priestly festival calendars of Leviticus 23 and Numbers 28. In other law codes of the Pentateuch (Exod 23:15-16;34:18-22; Deut 15), these two festivals are only dated using a wide seasonal definition, with no particular date. However, in Leviticus 23 and Numbers 28 they are both dated to the fifteenth of the seventh and first months respectively, Matzot being preceded by Passover by one day. ${ }^{38}$ What can be made of the night of the fifteenth, the date assigned to these festivals? McKay has noted, against the common assumption, that the night preceding the fifteenth of a lunar month hardly ever coincides with the full moon, which instead occurs more often on the thirteenth day of the month. This is because the lunar month does not begin with conjunction but rather with first visibility. The date of festivals, therefore, does not relate to the full moon, but rather to a schematic date, the fifteenth of the first or the seventh month. As McKay suggests at the end of his article, these dates bear closer relation to the solar cycle than they do to the lunar phases, the festivals constituting common schematic indications for the days of the equinox..$^{39}$ By way of analogy, Mesopotamian astronomical treatises relating to schematic months,

${ }^{36}$ For these festival calendars, see, e.g.: Alan Cooper and Bernard R. Goldstein, "The Festivals of Israel and Judah and the Literary History of the Pentateuch," JAOS 110 (1990) 19-31; Corinna Körting, Der Schall des Schofar: Israels Feste im Herbst (BZAW 285; Berlin: de Gruyter, 1999); Jan A. Wagenaar, Origin and Transformation of the Early Israelite Festival Calendar (BZABR 6; Wiesbaden: Harassowitz, 2005); Christoph Nihan, "Israel's Festival Calendars in Leviticus 23, Numbers 28-29 and the Formation of 'Priestly' Literature," in The Books of Leviticus and Numbers (ed. Thomas Römer; BETL 215; Leuven: Peeters, 2008) 177-231; Shimon Gesundheit, Three Times a Year: Studies on Festival Legislation in the Pentateuch (FAT 82; Tübingen: Mohr Siebeck, 2012). I will presently suggest an idea that does not appear in any of these previous studies.

${ }^{37}$ John McKay, “The Date of Passover and Its Significance," ZAW 84 (1972) 435-47. McKay's ideas were taken up by Matthias Albani, "Israels Feste im Herbst und das Problem des Kalenderwechsels in der Exilzeit," in Festtraditionen in Israel und im Alten Orient (ed. Erhard Blum and Rüdiger Lux; Veröffentlichungen der Wissenschaftlichen Gesellschaft für Theologie 28; Gütersloh: Gütersloher Verlaghaus, 2006) 111-56, at 134-35. Albani continues by claiming that Judean scribes adopted the Babylonian schematic year of 360 days because they wanted to abstain from admitting the divinity of the natural elements, which accompanies the use of a solar or lunar calendar.

${ }^{38}$ The exact layering of priestly literature is not of my direct concern here. Numbers 28 is usually taken to belong to $\mathrm{P}$ and Leviticus 23 to $\mathrm{H}$, but there may be P elements in Lev 23 and vice versa. See Israel Knohl, The Sanctuary of Silence (Minneapolis: Fortress, 1995) 8-45; Karl W. Weyde, The Appointed Festivals of YHWH (FAT 2/4; Tübingen: Mohr Siebeck, 2004) 11-44; Jacob Milgrom, Leviticus 23-27 (AB 3C; New York: Doubleday, 2001) 2054-56; Nihan, "Israel's Festival Calendars"; Horst Seebass, Numeri (BKAT 4; vol. 3; Neukirchen-Vluyn: Neukirchener Verlag, 2007) 246-52.

${ }^{39}$ McKay, "The Date of Passover," 446. 
such as table XIV of the series Enüma Anu Enlil, will record the full moon on the fifteenth day, and will place the equinox at the mid-month close to the New Year, either on the twelfth month of the year or on the first month. ${ }^{40}$

Priestly writers thus fixed the dates of Matzot and Sukkot at the mid-month, relying on a schematic view of the thirty-day month. In reality, since the calendar practiced in Judah was a lunar one, the fifteenth of the month would only rarely coincide with the equinox as suggested by the scheme. This is a natural and expected discrepancy, which would occur in any type of lunar calendar. If properly regulated, the practiced calendar will retain reasonable proximity to the schematic dates of the equinox across the years. ${ }^{41}$

The priestly authors must have followed one calendar or another in practice, but they did not feel the need to promote that particular calendar or to denigrate other calendrical systems. ${ }^{42}$ While such neutrality would be unthinkable at the height of the Second Temple period, when calendar disagreements took a central place in the religious discourse, earlier biblical authors did not consider the calendar to be of crucial importance and treated it as a matter-of-fact technicality. ${ }^{43}$ Priestly authors accordingly sought a way to indicate the middle of the month in a schematic way without addressing any particular calendrical situation. They had an exactly suitable mechanism for that purpose.

The use of schematic thirty-day months in the priestly festival calendars brings to mind an administrative-bureaucratic context, the author being a clerk

${ }^{40}$ Hermann Hunger and David Pingree, Astral Sciences in Mesopotamia (HdO 1.44; Leiden: Brill, 1999) 44-50. The equinox occurs on the fifteenth of Adar according to the astronomical text Enüma Anu Enlil XIV, but is registered as occurring on the fifteenth of Nisan in the astronomical compendium MUL.APIN. McKay continues his argument by claiming that the preference for a schematic month and the analogy with the Babylonian astronomical texts both point to a late date of P, after contact had been made with Mesopotamian science. I do not consider this argument compelling, however. Fixing the date of the equinox at the middle (fifteenth) of the month is not such cutting-edge astronomy that it would require an external scientific teaching. It is rather a quite simple scheme that could have been employed by less-skilled administrators of time in the Iron Age Levant.

${ }^{41}$ At this point I add some nuance to the position stated briefly by David Miano, Shadow on the Steps: Time Measurement in Ancient Israel (RBS 64; Atlanta: SBL Press, 2010) 48: "There is little doubt that the priestly calendar . . . also was lunisolar in character." While Miano is probably right that priests used a lunisolar calendar in practice, the preference to place festivals on the night of the fifteenth does not relate to the full moon but rather to a schematic view of the thirty-day month and of the march of the seasons.

${ }^{42}$ Wagenaar, Origin and Transformation, 145, reaches the conclusion that "the change in the way the beginning of the day was reckoned may suggest that pre-exilic Israel used an Egyptian-style 'civil' calendar. The year may, in accordance with the civil calendar of ancient Egypt, have comprised twelve months of thirty days and five epagomenal days." Wagenaar, however, is unaware of the concept of a schematic calendar, which was used for calculations but never followed in practice.

${ }^{43}$ For the idea that biblical authors did not feel the need to promote a specific calendrical agenda, see Jonathan Ben-Dov, "An Investigation into the Continuity between Biblical Literature and the Scrolls," in The Religious Worldviews Reflected in the Dead Sea Scrolls: Proceedings of the Fourteenth International Symposium of the Orion Center for the Study of the Dead Sea Scrolls and Associated Literature, 28-30 May, 2013 (ed. Menahem Kister and Michael Segal; STDJ 127; Leiden: Brill, 2018) 1-24. Some of the reasoning of that article is briefly reproduced here. 
or administrator who uses the language typical of that trade. ${ }^{44}$ Such a tendency is amply attested in the priestly literature, with the affection for long lists, conspicuous professional terminology, accounts laden with detail, and an unquenchable thirst for numbers. ${ }^{45}$

Outside the realm of the priestly literature, some later biblical authors used the 360-day framework when devising long-term calculations, just like their Mesopotamian predecessors. Thus, Gabriele Boccaccini has demonstrated how the numbers in Daniel 12:11-12 function according to that schematic mode of reckoning. ${ }^{46}$ While the Book of Daniel was written at a period in which calendar debates did play an important part in the religious worldview, the simpler 360-day scheme was retained for the purpose of multi-year calculations. ${ }^{47}$

\section{The 360-day Year in the Flood Narrative}

The dates in the flood account of Genesis 7-8 are bursting with scribal activity due to the universally accepted axiom that the flood lasted for one complete year (1 En. 106:15; Jub. 5-6; 4Q252 II, 1-3; 4Q254A III, 2; m. 'Arak. 10:3), a fact which prompted many Second Temple authors to anchor their calendar in the year of the flood. ${ }^{48}$ Indeed, calendrical undertones were associated with the story of the flood already in pre-biblical literature from the Ancient Near East. ${ }^{49}$ However, the Pentateuchal account never specified which kind of year was reflected in the flood narrative, leaving the debate as a battleground for various authors in later Second Temple times, when the calendar became a bone of contention. In contrast, in earlier times, i.e., when the flood story was written and edited, such a polemic was not pressing. Since the author or authors obviously did not have concrete archival

${ }^{44}$ See Menahem Haran, Temples and Temple Service in Ancient Israel (Oxford: Clarendon Press, 1978) 96, who mentions in this regard the priestly office of peqidim and its derivatives (2 Kgs 11:18; Jer 20:1-2; Ezek 44:11). I thank Jeffrey Stackert for the reference.

${ }^{45}$ Haran, Temples and Temple Service, 149. Early readers of the priestly source emphasized this aspect of $\mathrm{P}$ while in fact disregarding the literary qualities that do exist in it. A good summary of these views can be found in Sean E. McEvenue, The Narrative Style of the Priestly Writer (AnBib 50; Rome: Biblical Institute Press, 1971) 1-8.

${ }^{46}$ Gabriele Boccaccini, "The Solar Calendars of Daniel and Enoch," in The Book of Daniel: Composition and Reception (ed. John J. Collins and Peter W. Flint; 2 vols.; VTSup 83; Leiden: Brill, 2001) 2:311-28.

${ }^{47}$ It is important to trace the transition from the 360-day year to the 364-day year in more conscientious Second Temple writings. This phase was discussed by Boccaccini, "The Solar Calendars," and somewhat differently by Jonathan Ben-Dov, "Tradition and Innovation in the Calendar of Jubilees," in Enoch and the Mosaic Torah: The Evidence of Jubilees (ed. Gabriele Boccaccini and Giovanni Ibba; Grand Rapids: Eerdmans, 2009) 276-93.

${ }^{48}$ For this notion, see already Hermann Gunkel, Genesis (trans. M. E. Biddle; Macon, GA: Mercer University Press, 1997) 147 (original German edition published in 1901). In this article I will not discuss in detail the various modifications enacted by later Second Temple period authors to the year of the flood, but will rather focus on the versions of the biblical text, mainly MT, LXX, and SP.

${ }^{49}$ Guy Darshan, "The Calendrical Framework of the Priestly Flood Story in Light of a New Akkadian Text from Ugarit (RS 94.2953)," JAOS 136 (2016) 507-14. 
information on the year of the flood in hoary antiquity, the entire plan of that year as presented in the priestly account of Genesis $7-8$ was a schematic one, which was not meant to relate to any particular year nor to any particular astronomical phenomena. Rather, following an initial study by Fred Cryer, I believe that it reflects a schematic year of 360 days. ${ }^{50}$

Two central calendrical markers in Gen 6-8 stand out when seeking to characterize the kind of year conceived in the narrative. ${ }^{51}$ The first is the period of 150 days through which the water covered the land according to Gen 7:24; 8:3. This period was equivalent to five full consecutive months, as can be deduced from the date formulas in Gen 7:11 (seventeenth of month II) and 8:4 (seventeenth of month VII). Such a period of time, with five months equaling exactly 150 days, could not have existed in any of the calendars known or assumed in ancient Israel. A lunar calendar would have fixed at least some of these months as containing twenty-nine days only. Equally so, the sectarian 364-day year, which is sometimes assumed to have been practiced by biblical authors, ${ }^{52}$ would have required at least one longer

${ }^{50}$ Cryer, "The Interrelationships of Gen 5,32; 11,10-11"; this conclusion is implicitly supported by Martin Rösel, "Die Chronologie der Flut in Gen 7-8: Keine neuen textkritischen Lösungen," ZAW 110 (1998) 590-93; Albani, "Israels Feste im Herbst," 138.

${ }^{51}$ In this article I am concerned with the priestly layer or layers of the flood story and with the final redacted story. In addition to this narrative(s) there is another layer, whose interest in time measuring concentrates on time periods of seven and forty days, but without any interest in months and years. Literature on the identification of these layers and their interrelationship is vast and cannot be covered here. A convenient gateway to this affair is John A. Emerton, "An Examination of Some Attempts to Defend the Unity of the Flood Narrative in Genesis: Part I," VT 37 (1987) 401-20; idem, "An Examination of Some Attempts to Defend the Unity of the Flood Narrative in Genesis: Part II," VT 38 (1988) 1-21; later literature by Reinhard G. Kratz, The Composition of the Narrative Books of the Old Testament (trans. J. Bowden; London: T\&T Clark, 2005) 235-36; Baruch J. Schwarz, "The Flood Stories in the Pentateuch and the Point of Origin of History," in Sarah Japhet Jubilee Volume (ed. Moshe Bar-Asher et al.; Jerusalem: Bialik, 2008) 139-154 (Hebrew); Jan C. Gertz, "The Formation of the Primeval History," in The Book of Genesis: Composition, Reception, and Interpretation (ed. Craig A. Evans, Joel N. Lohr, and David L. Petersen; VTSup 152; Leiden: Brill, 2012) 107-35, at 124-26.

${ }^{52}$ S. Najm and Philippe Guillaume, "Jubilee Calendar Rescued from the Flood Narrative," JHS 5 (2005); Guillaume, Land and Calendar, 69-79; and more recently, idem, "Sifting the Debris: Calendars and Chronologies of the Flood Narrative," in Opening Heaven's Floodgates: The Genesis Flood Narrative, its Context and Reception (ed. Jason M. Silverman; Biblical Intersections 12; Piscataway, NJ: Gorgias Press, 2013) 57-83. The attempts by Najm and Guillaume to bypass this difficulty are not compelling. The authors take the 364-day year as their point of departure, striving to prove that the flood narrative corresponds to a pre-existing 364-day year, instead of searching objectively for the best possible solution. They are thus drawn into circular reasoning, as on pg. 2: "Since the result is not a whole number of weeks, we consider it an unlikely representation of P's system." In "Sifting the Debris," Guillaume is drawn into a set of far-reaching assumptions in order to posit that a sabbatical calendar had underlined the flood account. He assumes that the period of 150 days replaced "a period of two sabbatical seasons of an earlier version" (60; I do not see traces of such periods, however). He further assumes that the 360-day year, which is apparent in the flood account, is the result of a reform in the Persian calendar, between the Egypto-Achaemenid calendar and its Avestan predecessor (65; I do not see any of these calendars in the biblical account and have suggested an indigenous Judahite background). Finally, he explains that the flood was conceived as 
month of thirty-one days to occur within this stretch of five months. The story does not posit that the city council of Eridu, or Jerusalem, or anywhere else at the time of the flood, happened to decide on five round months! Rather, it uses schematic months, specifically in order to avoid the need to anchor the flood to any particular calendar practice. Given this period of 150 days, it is hard to deny that the author/ editor of these verses in Genesis 6-8 used schematic thirty-day months, together constructing a schematic year of 360 days.

The second suggestive calendrical piece of data in the flood account are the date formulas anchoring it in the framework of one year. Two such frameworks appear in Genesis 7-8: ${ }^{33}$ the first one assigns the flood to the confines of the six-hundredth year of Noah's life, beginning and ending exactly at the borders of that year (Gen $7: 6 ; 8: 13)$; the second one assigns less round figures for the dates of the beginning of the flood year (Gen 7:11) and of its end (8:14). Here the textual versions differ:

\begin{tabular}{|c|l|l|}
\hline & LXX & MT, SP \\
\hline Beginning (7:11) & 27 th of month II & 17 th of month II \\
\hline End (8:14) & 27 th of month II & 27 th of month II \\
\hline
\end{tabular}

Reading the data with an eye to schematic years, the situation seems clearest in the LXX version, where the flood lasted for exactly one year. ${ }^{54}$ Notably, this version of Gen 7:11 corresponds to the other previously mentioned chronological system of the flood, dating it through exactly one complete year. In terms of the calendar conflict, this is also the most naïve version, because although the flood lasted one year, there is no way to tell from the text which kind of year measured its duration. This fact is exactly what makes the LXX reading attractive for the text critic, being devoid of any bias for any particular calendrical doctrine. ${ }^{55}$ In historical-literary

a "suspension of time" but that this suspension applies only to part of the year of the flood (70; I can hardly see how the flood account, with so many dates in it, can be seen as a suspension of time). At the bottom line, the 364-day year is not the intuitive framework for explaining the dates in Gen 6-8. In the words of Fred Cryer: " . . . the only system not reflected in P's system is the 364-day schematic solar calendar of Qumran, Jubilees and the Book of Enoch" ("The Interrelationships of Gen 5,32; 11,10-11") 260 (italics in original).

${ }^{53}$ See the analysis by Kratz, The Composition of the Narrative Books, 235-36.

${ }^{54}$ I see no reason to accept the recent claim by Helen R. Jacobus ("Flood Calendars and Birds of the Ark in the Dead Sea Scrolls [4Q252 and 4Q254A], Septuagint, and Ancient Near East Texts," in Opening Heaven's Floodgates, 85-112, at 95) that "the LXX calendar consists of 12 or 13 months of 27-days each." Such months and such a year are not known to me from elsewhere, and I cannot see why the LXX translator (or an early Hebrew writer) would embrace such a peculiar calendar.

${ }^{55}$ In this proposal I share the basic principle expressed by Rösel, "Die Chronologie der Flut," 593, as well as by Ronald Hendel, "4Q252 and the Flood Chronology of Genesis 7-8: A TextCritical Solution," DSD 2 (1995) 72-79, at 78. Both authors acknowledge that the flood narrative had originally been devoid of motivation to promote any particular calendar. They both hesitate to read calendrical interests from Second Temple times into the biblical narrative. Neither of them, however, considers the solution suggested here, which to my mind gives the best explanation for the intentions of both the original story and its later reworkings. Specifically, Hendel's proposal that Gen 7:11 and 8:14 LXX both originate with a scribal mistake has been rejected by Rösel, 
terms, the LXX version of 7:11 is preferable because it corresponds with the similar annual framework in 7:6 and 8:13. In contrast, the reading of MT and SP in 7:11 introduces an additional gap of ten days, which reflects a (not necessarily successful) attempt to favor one kind of year against the other. In contrast to the view of most commentators, who see the LXX reading as a later correction, I follow Gunkel in stating that the correction should be sought in MT. ${ }^{56}$ This correction is a product of the later Second Temple period, and is thus the first in a chain of subsequent retellings and interpretations aimed to make the year of the flood correspond with "the right" kind of year: whether a lunar year (as propagated in MT and SP), a 364-day year (as in Jubilees and Qumran), or even a Julian year of 365 days (as propagated later by Ephrem). ${ }^{57}$

The priestly account in Genesis had not originally striven to make a point about any length of any year, but rather used schematic time indications, in the spirit of other ANE flood accounts, as we know them now. ${ }^{58}$ Explicit calendrical motivations did not arise before the calendar debates in the second, possibly third, century BCE. The various dates in MT, SP, Jubilees, and the Genesis Commentary 4Q252, are all

"Die Chronologie der Flut," as well as by Moshe Zipor, "The Flood Chronology: Too Many an Accident," DSD 4 (1997) 207-10.

${ }^{56}$ Gunkel, Genesis, 147. Contrast, for example, the preference for MT (with LXX hardly ever mentioned) by Gordon J. Wenham, Genesis 1-15 (WBC 1; Waco, TX: Word, 1985) 180.

${ }^{57}$ Ephrem (R. M. Tonneau, Sancti Ephraem Syri in Genesim et in Exodum Commentari [CSCO 152; Leuven: Peeters, 1955] 61) is quoted in Menahem Kister, "Studies in 4QMiqșat Ma asey Hattorah and Related Texts," Tarbiz 68 (1999) 317-71, at 362 (Hebrew).

${ }^{58}$ If the above is true, then all numbered dates in the priestly flood narrative had originally related to the twenty-seventh of the month, not the seventeenth. The number seventeen is a product of deliberate correction, reflected in MT and SP. Strikingly, the date of the twenty-seventh in the month corresponds to the date indicated in the Akkadian fragment of the flood narrative from Ugarit (RS 94.2953), which has recently been described as offering a concise temporal framework for the flood (Darshan, "The Calendrical Framework"). In that fragment, the date on which Ea commanded the protagonist to open a window in the ark was ina pi bibli ina rēš arhni (At the start of the time of the disappearance of the moon, at the beginning of the month; translation in ibid., 509). This time indication refers to the extended period of the moon's disappearance, the so-called "interlunium" preceding the actual new moon by as much as three days and beginning with the bubbulum (disappearance, darkening, or, often, last visibility). In the original flood account as attested in the LXX and partly in MT, that period did not begin on day one of the month but rather three days earlier. For the interlunium, see Karel van der Toorn, Family Religion in Babylonia, Syria and Israel (Leiden: Brill, 1996) 49-50. Last visibility of the moon on day twenty-seven of the month is not infrequent, as for example in SAA 8, 346, and in many attestations of the phenomenon called KUR in the "Lunar six." I thank John Steele for his advice on this point. Darshan ("The Calendrical Framework," 512) cited Gen 8:5 "on the first day of the month" as a parallel to the above quoted line from the Ugarit fragment. However, the twenty-seventh day of the month, which recurs in the (pre-corrected) flood narrative, is a much better parallel. It is worth noting that the flood traditions surveyed by Darshan reveal another schematic time indication: the fifteenth day of the month Daisios, as noted by Berossus (FGrH 680 F4b; see Darshan, "The Calendrical Framework," 512). Darshan's association of this datum with the seventeenth of the month in Gen 7:11 is unwarranted, since the latter date is a scribal product, the original date being the twenty-seventh of the month. Berossus's date should thus be seen as a schematic time indication, a rather expected characteristic of ANE flood accounts. 
scribal products, aimed to harness the flood narrative to a battle that it had never been meant to fight. Kister rightly states that all the various flood chronologies in Second Temple literature seem forced and detached from the original account, and thus cannot be taken as an organic continuation of the tradition. ${ }^{59}$

Although the LXX is a Second Temple text in and of itself, in the present case it preserves an ancient reading, which reflects the original flood account based on a schematic year of 360 days. ${ }^{60}$ The LXX reading is preferable because the indicated dates mark exactly one year without supplying any hinge on which to hang a preference for any particular year. ${ }^{61}$ The MT-SP reading, which measures the length of the flood by one year plus eleven days (from II/17 until II/27 in the next year), is a sectarian reading: it aims to show that, while the flood indeed lasted for one complete solar circuit of 364/5 days, the calendar dates invoked in the narrative are not counted by that system but rather by the common lunar year of 354 days. The scribe who created this reading was following a lunar calendar. ${ }^{62}$ MT and SP are thus interested parties in the calendar debate, while the reading in LXX is indifferent to it, hence also earlier. ${ }^{63}$

59 "Studies in 4QMMT," 363.

${ }^{60}$ This reasoning modifies the argumentation presented by Kister, "Studies in MMT," 363. Although I agree with Kister's general line of argument, I reject his preference for MT over LXX. Kister is not aware of the possibility that the biblical account operated with a schematic 360 -day year and was thus free of commitment to any other calendrical tradition.

${ }^{61}$ An idea with similar implications was promoted by Emile Vogt, "Note sur le calendrier du deluge," Biblica 43 (1962) 212-16 (This note is integrated in a larger article by Henri Cazelles, "Sur les origins du calendrier des Jubilés," 202-16). Vogt suggested that all dates in Gen 7:11; 8:4; and 8:14 had originally marked the seventeenth, with the reading of 8:14 corrected to the twentyseventh day of the month in order to polemicize against what he calls the priestly calendar of 364 days. This proposal creates the same effect as my proposal, with the dates reflecting precisely one year, without indicating the exact nature of that year. The problem with Vogt's idea is, however, that day seventeen of the month is not attested in any textual witness of Gen 8:14.

${ }^{62}$ Moreover, the scribe who had introduced the correction in MT-SP Gen 7:11 was later forced to change also the date in 8:4, which marks one half-year, midway through the flood. LXX reads in this verse the twenty-seventh day, employing the same day of the month across the board. In contrast, MT-SP read here the seventeenth, having had to change the original reading on account of the change in $8: 14$.

${ }^{63}$ Another secondary reading was introduced elsewhere in MT as a sectarian calendrical statement: the addition of the words ממחרת הפסח (the day after the Pesah) in Josh 5:11. These words are absent in LXX ad loc. The lateness of this gloss is apparent since the sacrifice of the first sheaf does not take place on the day after the Passover (I/14) in either of the known halakhic traditions. This gloss indicates the date of the Pharisaic rabbinic omer celebration on I/16, and should thus be seen as a Pharisaic gloss. For this late glossator, Passover and the Matzot Festival are one and the same,

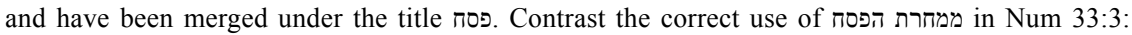
"They set out from Rameses in the first month, on the fifteenth day of the first month. On the morrow of the Passover offering" [NJPS]). That the MT of Josh 5:11 preserves a Pharisaic gloss derives from the argumentation of Joseph M. Baumgarten, "The Calendars of the Book of Jubilees and the Temple Scroll," VT 37 (1987) $71-78$, at 72. 


\section{Conclusion}

In the present article, I put forward various arguments to support the claim that some ancient Judahite writers and administrators used a schematic calendar of 12 X 30 days. This calendar operated alongside the one in practice, and was used for long-term calculations and generic statements of time, both in administration and in law and literature. While not all of the evidence collected here is compelling on its own, I believe that altogether it creates a convincing picture. The analysis of the flood chronology, in contrast, will stand regardless of the validity of the archeological part of my argument.

As in other cultures of the Ancient Near East, Judah of the Iron Age had also known a schematic year as part of its administrative heritage. This year did not constitute "a calendar" in the narrow sense, because no civil or religious activities were dated on its basis. Rather, it was an administrative framework used by clerks and administrators for long-term calculations and routine office tasks. This system is attested by a number of carved bone plaques discovered in major Judahite sites of the Iron Age II, although admittedly the plaques may have also been used with a lunar calendar. Interestingly, these devices seem to divide the months, if at all, into units of five or ten days, without recourse to the seven-day week. This evidence agrees with later sources, showing that the week began to be used as an administrative (rather than cultic) unit only in late Second Temple times.

Another manifestation of the same schematic year appears in literary sources, mostly related to priestly writers. This is not surprising given the bureaucratic character of the priestly prose. The dating of Sukkot and Matzot to the middle of the month in Lev 23 and Num 28 seems to reflect a schematic placement of the equinoxes on the fifteenth of months I and VII. The use of a schematic year gives the best explanation known to me for the dates in the priestly account of the flood. Preferring the LXX reading of Gen 7:11 for the date of the flood's beginning, I claimed that the original priestly story or stories sketched the year of the flood within the exact confines of one schematic year. The reading in MT and SP reflects an emendation, aiming to highlight the difference between the schematic year and the lunar year practiced at the time when the change was inserted. Scribal activity with regard to the dates in the flood account arose only in later Second Temple times, since calendar debates were not present, or at least not pressing, earlier.

The "discovery" of the 360-day year in ancient Israel answers some of the questions that had led scholars to posit the existence of a 364-day year in Iron Age Judah. With that hypothesis disproven, it is my hope that scholars will accept the exegetical benefits of the 360-day year and will further explore its implications for priestly literature and legislation. ${ }^{64}$

${ }^{64}$ See, for example, Jeffrey Stackert, "The Regulation of Time and the Priestly Sanctuary: Between Literature and Material Culture," in Contextualizing Jewish Temples (ed. Tova Ganzel and Shalom Holtz; BRLA 64; Leiden: Brill, 2020) 49-64. 